\title{
Presence of Complement-fixing Anti-Endothelial Cell Antibodies in Systemic Lupus Erythematosus
}

\author{
Douglas B. Cines, Alan P. Lyss, Miriam Reeber, \\ Mahin Bina, and Raphael J. DeHoratius \\ Departments of Medicine, Pathology, and Anatomy, University of \\ Pennsylvania, Philadelphia, Pennsylvania 19104; Department of \\ Medicine, Hahnemann Medical College, Philadelphia, \\ Pennsylvania 19102
}

bstract. Vasculitis in systemic lupus erythematosus (SLE) is associated with the deposition of $\mathrm{IgG}$ and complement in blood vessel walls. However, it is not known whether immune injury to endothelial cells is a part of this process. Therefore, we used a solid phase radioimmunoassay to study the ability of IgG from normal human sera and sera from patients with SLE to bind to endothelial cells. In this assay, cultured human umbilical venous endothelial cells were sequentially incubated with normal or SLE sera, goat anti-human IgG, and ${ }^{125} \mathrm{I}$-labeled staphylococcal protein A (*SPA). After exposure to normal sera, $2.5 \pm 0.5 \%$ (mean \pm SD) of the added *SPA bound to the cells, whereas after exposure to SLE sera $13.8 \pm 7.6 \%$ of the added *SPA bound to these cells. This difference in binding was highly significant $(P<0.001)$. Binding was partially reduced when SLE sera were preincubated with B-lymphocytes or monocytes, but not after exposure to erythrocytes, platelets, or T lymphocytes.

Incubation of endothelial cells with the $7 \mathrm{~S}$ fraction of SLE sera or with the $F\left(a b^{\prime}\right)_{2}$ fragment of SLE-IgG resulted in the deposition of $>80 \%$ as much $\mathrm{IgG}$ as was deposited on endothelial cells by whole serum. However, since higher molecular weight fractions $(>7 S)$ of SLE sera were also active, we tested the capacity of endothelial cells to bind IgG complexes. Endothelial cells bound heataggregated IgG (HA-IgG) in a saturable manner at one log concentration below the binding of normal mono-

\footnotetext{
Dr. Cines is the recipient of a Research Career Development Award (1K04-HL00956) from the National Institutes of Health.

Received for publication 10 February 1983 and in revised form 1 November 1983.
}

J. Clin. Invest.

(C) The American Society for Clinical Investigation, Inc.

0021-9738/84/03/0611/15 \$1.00

Volume 73, March 1984, 611-625 meric IgG. Binding of HA-IgG to endothelial cells was markedly enhanced by preincubation with a serum source of complement. Both HA-IgG and SLE-IgG also bound to freshly obtained endothelial cells in suspension, as detected by automated fluorescence flow cytometry.

Binding of SLE-IgG and HA-IgG to endothelium initiated complement activation, deposition of the third component of complement, and disruption of the monolayer. In addition, SLE-IgG and HA-IgG caused endothelial cells to secrete prostacyclin and caused the adherence of platelets, confirmed by scanning electron microscopy.

These studies demonstrate that IgG anti-endothelial antibodies are present in the sera of patients with active SLE. These sera may also contain IgG complexes that are capable of binding to endothelial cells. The association of IgG and complement with endothelial cells may initiate vascular injury in SLE and other human disorders.

\section{Introduction}

Antibody and complement are found within blood vessel walls of patients with systemic lupus erythematosus (SLE) ${ }^{1}$ and other forms of human vasculitis (1). Although immune complexes and autoantibodies persist in the systemic circulation of these patients, vascular injury itself is episodic and restricted. The lesions of each classic form of vasculitis have a distinct appearance. They generally affect vessels of a particular size and only certain organs are involved (1). The reasons for this specificity remain unclear, and the target of immune injury within the vessel wall remains uncertain (2).

1. Abbreviations used in this paper: $\mathrm{ACD}$, acid citrate dextrose; $\mathrm{C} 3$, third component of human complement; FITC, fluorescein isothiocyanate; HA-IgG, heat-aggregated normal human IgG; $\mathrm{PGF}_{2 \alpha}$ and PGI, prostaglandins $F_{1 \alpha}$ and I, respectively; SLE, systemic lupus erythematosus; *SPA, ${ }^{125}$ I-labeled staphylococcal protein A; TTP, thrombotic thrombocytopenic purpura. 
Endothelial cells appear to possess certain characteristics that make them a candidate for immune vascular injury. They have been shown to be important both in presenting antigen to lymphocytes (3) and in regulating lymphocyte migration through vessel walls $(4,5)$. In addition, endothelial cells have been shown to express ABH, HLA, D/DR, and endothelialspecific antigens on their cell surface (6-10). Moreover, since these cells are in direct contact with circulating antibody, immune complexes, complement, and effectors of cell-mediated immunity, immune injury to endothelial cells may play a role in the pathogenesis of several immune vascular disorders.

Several studies have shown that endothelial injury modifies the expression of endothelial surface antigens and promotes active binding of immune complexes to these cells $(11,12)$. However, it is less certain whether uninjured endothelium has the capacity to bind immune complexes or autoantibodies (1218). In this study we asked whether patients with SLE have IgG antibodies or IgG-containing immune complexes that bind to normal human endothelial cells. Because normal endothelium is a nonthrombogenic surface, we also asked whether immune injury caused by IgG and complement would alter the association of endothelial cells with human platelets.

\section{Methods}

Endothelial cell culture. Endothelial cells were harvested from human umbilical cord veins by collagenase digestion using established methods $(12,19,20)$. Endothelial cells were grown in medium 199 (Gibco Laboratories, Grand Island, NY) supplemented with $10 \%$ heat-inactivated fetal bovine serum (Flow Laboratories, Inc., McLean, VA), penicillinstreptomycin-fungizone (Gibco Laboratories) and endothelial cell growth supplement, which was prepared according to the method of Maciag et al. (21) and Booyse et al. (22). In some experiments endothelial cells were studied in suspension either immediately after isolation or following overnight incubation in conditioned medium. In other experiments, confluent monolayers were prepared by pretreating plastic surfaces with human fibronectin, which had been purified by gelatin affinity chromatography (Difco Laboratories, Detroit, MI) (21). In these experiments endothelial cells were plated directly onto fibronectin-coated 96-well microtiter plates (Linbro Chemical Co., Hamden, CT), 24-well microtiter plates (Costar Data Packaging, Cambridge, MA), or $100 \times 20$-mm tissue culture dishes (Falcon Labware, Div. of Becton, Dickinson \& Co., Oxnard, CA). In individual experiments, confluent endothelial cells after 3-5 d in culture were passaged by a 3-5-min exposure to $1 \%$ trypsin (Gibco Laboratories) at $37^{\circ} \mathrm{C}$ and the reaction terminated with an equal volume of soybean trypsin inhibitor $(2.5 \mathrm{mg} / \mathrm{ml})$ in medium 199 (Gibco Laboratories). After centrifugation, the cells were divided in thirds and cultured as above (21). Both the primary cultures and the passaged cells were positive for Factor VIII antigen (23). For performance of immunofluorescence microscopy, endothelial cells were grown directly on sterile 12-mm² coverslips (SGA Scientific, Inc., Bloomfield, NJ), washed twice in phosphate-buffered saline (PBS), and fixed for $10 \mathrm{~min}$ at $22^{\circ} \mathrm{C}$ with fresh $2 \%$ formaldehyde.

Sources of human IgG. We used several sources of human IgG to sensitize endothelial cells. Sera were obtained from normal healthy volunteers; from three patients with IgG myeloma; from nine patients with thrombotic thrombocytopenic purpura (TTP), before exchange transfusion; and from 27 patients with active SLE, each of whom fulfilled the diagnostic criteria of the American Rheumatism Association. Sera were generally used at a 1:2 dilution. Immune complex-like activity in each serum was assessed by the level of ${ }^{125} \mathrm{I}$-Clq precipitins as determined by Dr. David Koffler (Hahnemann Hospital, Philadelphia, PA) (24).

Purified IgG was prepared from sera by ammonium sulfate precipitation, anion exchange chromatography using quarternary amino ethyl Sephadex, and Sephadex G-200 chromatography (25). Aggregated IgG (HA-IgG) was prepared before each experiment by heating monomeric IgG at $63^{\circ} \mathrm{C}$ for $20 \mathrm{~min} . \mathrm{F}\left(\mathrm{ab}^{\prime}\right)_{2}$ fragments of purified normal IgG and SLE-IgG were prepared by pepsin digestion (26) followed by gel filtration on Sephadex G-150. Normal $F\left(a^{\prime}\right)_{2}$ fragments, as well as normal Fc fragments, were also obtained from Cappel Laboratories, Cochranville, PA. The purity of the $F\left(a b^{\prime}\right)_{2}$ and $F c$ fragments was assessed immunologically by Ouchterlony analysis using specific antisera (CalbiochemBehring Corp., American Hoechst Corp., San Diego, CA), and purity was assessed chemically by sodium dodecyl sulfate-polyacrilamide disc gel electrophoresis (27).

Whole serum from normals and patients with SLE was also fractionated by Sephadex G-200 chromatography. Total protein in each 10$\mathrm{ml}$ fraction was determined by light adsorbance at $280 \mathrm{~nm}$, and the concentration of IgG was quantitated by radial immunodiffusion (28) (Hyland Laboratories, Costa Mesa, CA). Each fraction was then directly tested for its capacity to bind IgG to endothelial cells. Patient and normal sera were also fractionated using continuous 5-35\% sucrose density gradients (29). Four equal protein pools were prepared consisting of protein fractions $<7 \mathrm{~S}, 7 \mathrm{~S}, 7-19 \mathrm{~S}$, and $>19 \mathrm{~S}$ in size. Each of the pools was dialyzed for $18 \mathrm{~h}$ at $4^{\circ} \mathrm{C}$ against PBS. The amount of IgG in each fraction was quantitated by radial immunodiffusion and the concentration of $\mathrm{IgG}$ in all fractions was equalized by the addition of PBS (28). Each fraction was then tested for its capacity to bind IgG to endothelial cells.

Adsorption studies. IgG and its $\mathrm{F}\left(\mathrm{ab}^{\prime}\right)_{2}$ fragment were adsorbed with a variety of normal cells in order to detect the presence of isoantibodies in these sera as well as to determine whether other cells possess antigens that are also present on endothelial cells. Each source of IgG was incubated with an equal volume of packed cells for $1 \mathrm{~h}$ at $37^{\circ} \mathrm{C}$ and $18 \mathrm{~h}$ at $4^{\circ} \mathrm{C}$ before use. Unadsorbed IgG served as a background control.

Erythrocytes and platelets were isolated either from fresh whole blood or from platelet concentrates (25). Mononuclear cells were prepared from heparinized whole blood by density gradient centrifugation using lymphocyte separation medium (Litton Bionetics, Kensington, MD). To further purify the mononuclear fraction, the cells were allowed to adhere to $150-\mathrm{cm}^{2}$ flasks (Corning Glass Works, Corning Medical and Scientific, Corning, NY) for $20 \mathrm{~min}$ at $37^{\circ} \mathrm{C}(30)$. After exposure to trypsin, the adherent cells were removed from the plastic with a rubber policeman; $>95 \%$ of these cells showed positive staining for nonspecific esterase. The nonadherent population was further subdivided into $T$ cells and $B$ cells by double rosetting with fresh sheep erythrocytes treated with 2-amino-ethylisothiouranium bromide (31). To obtain a sufficient mass of endothelial cells for these studies, primary endothelial cell cultures from $\sim 10$ donors were subcultured through four passages.

Assessment of endothelial-associated IgG by solid phase radioimmunoassay (RIA). The binding of IgG to endothelial cells was quantitated using a solid phase RIA. Primary cultures were grown directly on 96well microtiter plates. After 2-4 d in culture, the cells were confluent and were fixed by incubation with $0.0625 \%$ paraformaldehyde (Fisher Scientific Co., Pittsburgh, PA) for $10 \mathrm{~min}$ at $22^{\circ} \mathrm{C}$. Before fixation, $>95 \%$ of the cells excluded trypan blue. After fixation, cells could be stored at $0^{\circ}-22^{\circ} \mathrm{C}$ for at least $7 \mathrm{~d}$ without a change in their binding capacity. Endothelial monolayers were incubated with $100 \mu \mathrm{l}$ of a source of human IgG diluted in Hanks' balanced salt solution (HBSS) (Microbiological 
Associates, Walkersville, NY) for $60 \mathrm{~min}$ at $22^{\circ} \mathrm{C}$, washed three times in HBSS containing $1 \%$ human serum albumin (Sigma Chemical Co., St. Louis, MO) by inverting the plate, incubated with a 1:200 dilution of goat IgG anti-human IgG (heavy chain specific) (Cappel Laboratories) at $22^{\circ} \mathrm{C}$ for $60 \mathrm{~min}$, and washed. They were then incubated at $22^{\circ} \mathrm{C}$ for 60 min with staphylococcal protein A (Pharmacia Fine Chemicals, Piscataway, NJ), which had been radiolabeled with $\mathrm{Na}^{125}$ ( $\left.{ }^{*} \mathrm{SPA}\right)$ (New England Nuclear, Boston, MA) by the chloramine-T method (32). Following four vigorous washes to remove unbound *SPA, the endothelial cells were removed from the wells with cotton applicator swabs (Cheeseborough Ponds, Inc., Greenwich, CT). The microtiter plates were then viewed using a Nikon (model MS) inverted-phase microscope to determine whether endothelial cells remained adherent. Essentially all endothelial cells were removed from the wells using the cotton applicators. The swabs were then counted for gamma emission (Gamma 8000, Beckman Instruments, Inc., Fullerton, CA). Each experimental point was performed in triplicate. The endothelial cell monolayer remained $100 \%$ confluent during the incubations and washings, as assessed by phase-contrast microscopy. Experiments performed in parallel using endothelial cells that had not been fixed showed results comparable to fixed cells. However, we observed a variable loss of endothelial cells from the monolayer during incubation and washing, which occasionally exceeded $15 \%$ of the total number of cells. In the absence of a source of human IgG, $0.6 \pm 0.2 \%$ (mean \pm SEM, $n=>100$ ) of the available *SPA bound to the endothelial monolayer. In other experiments, the fixed endothelial monolayers were preincubated with a $10 \%$ solution of bovine serum albumin (Sigma Chemical Co.), human serum albumin (Sigma Chemical Co.) or normal rabbit serum as controls. The binding of HAIgG to endothelial monolayers was unaffected by preincubation of the monolayer with either source of albumin or with normal rabbit serum. In the adsorption studies described above, the extent of adsorption was determined by measuring the residual binding of IgG to endothelia cells using *SPA. The data are expressed as the percentage of the total endothelial bound *SPA that remained after adsorption. In individual experiments, $\mathrm{Fc}$ fragments of IgG were quantitated as protein (28), labeled with $\mathrm{Na}^{125} \mathrm{I}(32)$ and heat aggregated at $63^{\circ} \mathrm{C}$ for $20 \mathrm{~min}$. Endothelial monolayers were preincubated with varying concentrations of unlabeled HA-IgG, monomeric IgG, or human albumin for $45 \mathrm{~min}$ at $37^{\circ} \mathrm{C}$ and washed three times. The endothelium was then incubated with ${ }^{125} \mathrm{I}-\mathrm{Fc}$ fragments for $45 \mathrm{~min}$ at $37^{\circ} \mathrm{C}$, washed four times and the endothelial cell radioactivity determined.

Interaction of HA-IgG with the complement system. To determine if preincubation of HA-IgG with normal serum affected its subsequent binding to endothelial cells, varying concentrations of HA-IgG (0-200 $\mu \mathrm{g}$ in $100 \mu \mathrm{l})$ were incubated with an equal volume of fresh normal human serum for $60 \mathrm{~min}$ at $37^{\circ} \mathrm{C}$ and subsequently added to endothelial cell monolayers. Goat anti-human IgG (diluted 1:200) or goat anti-C3 (third component of human complement) (diluted 1:20) (Cappel Laboratories) was then added to the endothelial cells and the binding of *SPA was determined. In parallel experiments, HA-IgG was also incubated with normal serum that had been heat inactivated $\left(56^{\circ} \mathrm{C}\right.$ for $60 \mathrm{~min}$ ), or to which EDTA ( $10 \mathrm{mM}$ final concentration) had been added, in order to determine whether activation of the complement system was required to modify the binding of HA-IgG.

We also determined whether HA-IgG activated the complement system following its binding to endothelial cells. Endothelial cells were sensitized with HA-IgG (10-100 $\mu \mathrm{g} / \mathrm{HA}-\mathrm{IgG}$ per well) and subsequently overlayed with $100 \mu l$ of a 1:20 or 1:40 dilution of normal human serum, heat-inactivated serum, or EDTA-serum. The binding of anti-C3 to the endothelial cells was then determined as above. C3 deposition onto endothelial cells was also confirmed by directly measuring the binding of ${ }^{125} \mathrm{I}$-IgG-anti-C3 (25). In this experiment, ${ }^{125} \mathrm{I}$-labeled rabbit IgG not having antibody (anti-C3) activity served as the control to assess the effect of complement activation on the nonspecific binding of the antiglobulin reagent per se. Binding was similarly determined using normal serum in which complement had been inactivated by heat or EDTA (10 mM).

Assessment of IgG-endothelial cell interactions by fluorescence anal$y$ sis. The interaction of human IgG with endothelial cells was studied using the Spectrum III fluorescence analyzer (Ortho Diagnostic Systems, Inc., Westwood, MA). Fresh human umbilical venous endothelial cells were obtained in suspension by collagenase digestion $(12,19,20)$ and the adherent erythrocytes were removed by the addition of lysing reagent (Ortho Pharmaceutical, Raritan, NJ). The endothelial cells were washed twice and resuspended at a concentration of $2 \times 10^{5}$ cells $/ \mathrm{ml}$ in RPMI 1640 medium with $10 \%$ heat-inactivated fetal calf serum (Gibco Laboratories). Cell suspensions were also prepared from endothelial monolayers following exposure to $1 \%$ trypsin for 3-5 min. Endothelial cells were incubated at $37^{\circ} \mathrm{C}$ for $4-18 \mathrm{~h}$ in serum-containing medium to allow for reexpression of cell surface antigens and then incubated with a source of human $\operatorname{IgG}(1 \mathrm{ml})$ at $22^{\circ} \mathrm{C}$ for 1 hour. After washing three times in the serum-free medium they were incubated with fluorescein isothiocyanate (FITC)-conjugated goat $\mathrm{F}\left(\mathrm{ab}^{\prime}\right)_{2}$ anti-human IgG (gamma chain specific) antibody (Tago, Inc., Burlingame, CA) at a 1:40 dilution at $37^{\circ} \mathrm{C}$ for $30 \mathrm{~min}$. Following three additional washes, the cells were resuspended in cold $\mathrm{Ca}^{++}$- and $\mathrm{Mg}^{++}$-free PBS containing $0.1 \%$ bovine serum albumin and $0.01 \%$ sodium azide.

Endothelial cells in suspension were also incubated at $4^{\circ} \mathrm{C}$ with several sources of murine monoclonal antibodies and FITC-conjugated goat $F\left(a b^{\prime}\right)_{2}$ anti-mouse $F\left(a b^{\prime}\right)_{2}$ (Tago, Inc.). Murine monoclonal antibodies OKT3 (panagglutinin), OKT11 (sheep erythrocyte rosette receptor), OKT9 (transferrin receptor), OKMI, and OK-Ia-I (D/DR antigen) were obtained from the Ortho Diagnostic Systems, Inc. (Westwood, MA). $A_{2} A_{9}$ is an $\operatorname{IgG}_{2}$ murine monoclonal anti-platelet antibody that binds to the platelet glycoprotein IIb-IIIa complex and competitively inhibits the binding of fibrinogen to stimulated platelets (33). P3X63 is the nonantibody Ig-secretory product of the parent myeloma cell line. D-1-6, 691, and SK-379 are monoclonal anti-Ia antibodies developed by immunization with melanoma cells and were the gift of Dr. Alonzo Ross (Wistar Institute, Philadelphia, PA). CX-2.1 is a monoclonal antihuman D/DR antibody prepared against myeloid leukemia cells and was a gift of Dr. James Hoxie (University of Pennsylvania). 63-D-3 (Bethesda Research Laboratories, Bethesda, MD) is a monoclonal antibody that reacts strongly with peripheral blood monocytes and weakly with normal granulocytes. W6/32 (anti-HLA framework) was purchased from Pel-Freeze Biologicals, Rogers, AK. B1, the anti-B cell antibody, and $\mathrm{J} 5$, the antibody reactive with the common acute lymphocytic leukemia antigen, were purchased from Coulter Electronics, Inc., Hialeah, FL. Rabbit anti-mouse Ia alloantiserum was obtained from Cedarlane Laboratories, Inc. (Hornby, Ontario, Canada).

Endothelial cells exposed to various human, rabbit, and murine Ig were reacted with the corresponding FITC-conjugated anti-Ig and analyzed on an Ortho Spectrum III fluorescence cell analyzer (Ortho Diagnostic Systems, Inc.) by the method of Ip et al. (34) using the 1129 66 program designed for large cells, thereby excluding normal circulating leukocytes (Fig. $2 \mathrm{~A}$ ). Positive and negative regions were defined using P3X63 as a negative control and adjusting the analyzer threshold such that $<1 \%$ of the cells were considered positive. Using this program, only a single population of cells positive for Factor VIII antigen was identified on the basis of the right angle and the narrow forward light scattering 
properties of the individual cells. The extent of binding of FITC-conjugated anti-Ig to this cell population was determined by quantitating the magnitude of the green fluorescence signal (34). Approximately 2,000 cells were analyzed in each experiment. Both the percentage of cells showing increased fluorescence above background and the degree of fluorescence, expressed as the "mean positive channel," were determined (34).

The binding of IgG to endothelial cells was confirmed by fluorescence microscopy. Each source of human IgG was directly conjugated with FITC, isomer I (Sigma Chemical Co.), to a molar ratio of FITC to IgG of between 3 and 4:1 by established methods (35). Endothelial cells were fixed with $2 \%$ formalin for $10 \mathrm{~min}$ at $22^{\circ} \mathrm{C}$. After three washes in PBS, the cells were incubated with $50 \mu$ l of conjugated immunoglobulin (0.1$1.0 \mathrm{mg} / \mathrm{ml}$ ) for $45 \mathrm{~min}$ at $37^{\circ} \mathrm{C}$. The cells were washed and the binding was assessed using the Zeiss MC-63 fluorescence microscope (Carl Zeiss, Inc., New York).

We also performed studies using unfixed endothelial cells to determine if IgG would bind to the surface of the endothelium. Fluoresbrite fluorescent monodisperse carboxylated microspheres $(0.84 \mu \mathrm{m}$ in diameter) were obtained from Polysciences, Inc., Warrington, PA. $1 \mathrm{ml}$ of washed beads, containing $\sim 10^{8}$ spheres, was incubated with $1 \mathrm{mg}$ of HA-IgG or $1 \mathrm{mg}$ of human serum albumin at $4^{\circ} \mathrm{C}$ for $18 \mathrm{~h}$ and resuspended in Dulbecco's PBS containing 3\% human serum albumin. The efficiency of coupling protein to these beads was $>95 \%$ as measured by the optical density of the residual unbound protein. Endothelial monolayers on fibronectin-covered glass coverslips were washed twice with the albumincontaining buffer, incubated with $30 \mu \mathrm{l}$ of the protein-coated beads for $30 \mathrm{~min}$ at $37^{\circ} \mathrm{C}$, and thoroughly washed to remove unbound beads. The cells were then fixed with $1 \%$ fresh formaldehyde, washed and photographed in phase contrast and for immunofluorescence as detailed above. We further assessed the integrity of the endothelial cell surface membrane using FITC-conjugated rabbit IgG anti-rat cytoplasmic myosin (gift of Dr. Vivian Nachmias, Department of Anatomy, University of Pennsylvania) (36). Human endothelial cells permeabilized in $1 \%$ acetone showed intense cytoplasmic fluorescence following incubation with this antibody. In contrast, the unfixed endothelial cells used in this study, as well as endothelial cells fixed in $0.0625 \%$ paraformaldehyde, did not bind anticytoplasmic myosin, indicating that the integrity of the surface membrane had been retained.

Secretion of prostaglandin $I_{2}\left(P G I_{2}\right)$; adherence of platelets. The release of $\mathbf{P G I}_{2}$ from endothelial cells was assessed by measuring its stable metabolic end product 6-keto-prostaglandin $F_{1 \alpha}$ (6-keto-PGF $\left.F_{1 \alpha}\right)$. Primary endothelial cultures were incubated with bovine thrombin (Parke-Davis, Co., Div. of Warner-Lambert, Inc., Morris Plains, NJ) or a source of human IgG for 10-120 min. The supernatant was harvested and the level of 6-keto-PGF $F_{1 \alpha}$ was quantitated by a competitive RIA (New England Nuclear).

The adherence of platelets to endothelial monolayers was performed by a modification of published methods (37). Human platelets were isolated in acid citrate dextrose (ACD) and radiolabeled with ${ }^{51} \mathrm{Cr}$ for $30 \mathrm{~min}$ at $37^{\circ} \mathrm{C}\left({ }^{51} \mathrm{Cr}-\mathrm{Na}\right.$, New England Nuclear) in $10 \mathrm{ml}$ Tyrode's buffer $\mathrm{pH} 7.2$ to which $0.4 \mathrm{ml}$ ACD had been added. The unincorporated ${ }^{51} \mathrm{Cr}$ was removed by washing two times in ACD/Tyrode's buffer, and the labeled platelets were resuspended at $1 \times 10^{8}$ cells $/ \mathrm{ml}$ and added to washed endothelial monolayers, previously exposed to thrombin (0.1$2.0 \mathrm{U} / \mathrm{ml}$ ) or a source of human IgG for 10-60 min. After incubation with ${ }^{51} \mathrm{Cr}$-labeled platelets $(1 \mathrm{ml})$ at $37^{\circ} \mathrm{C}$ for $30-120 \mathrm{~min}$, the monolayer was again vigorously washed, and the presence of adherent platelets was assessed by phase-contrast microscopy. The endothelial monolayer and adherent platelets were then removed by cotton applicator swabs, which were counted for gamma emission as described above. Monolayers were also fixed with $2 \%$ gluteraldehyde and processed by critical endpoint drying. Scanning electron microscopy was then performed with an SEM 500 scanner (Phillips Electronic Instruments, Inc., Mahwah, NJ) (12).

Statistics. Comparison of the binding of IgG from different patient sera to endothelial cells was carried out using the two-tailed $t$ test.

\section{Results}

\section{Binding of $\operatorname{IgG}$ to endothelial cells}

We studied the binding of human IgG to endothelial cells derived from human umbilical veins. Endothelial cells in a monolayer

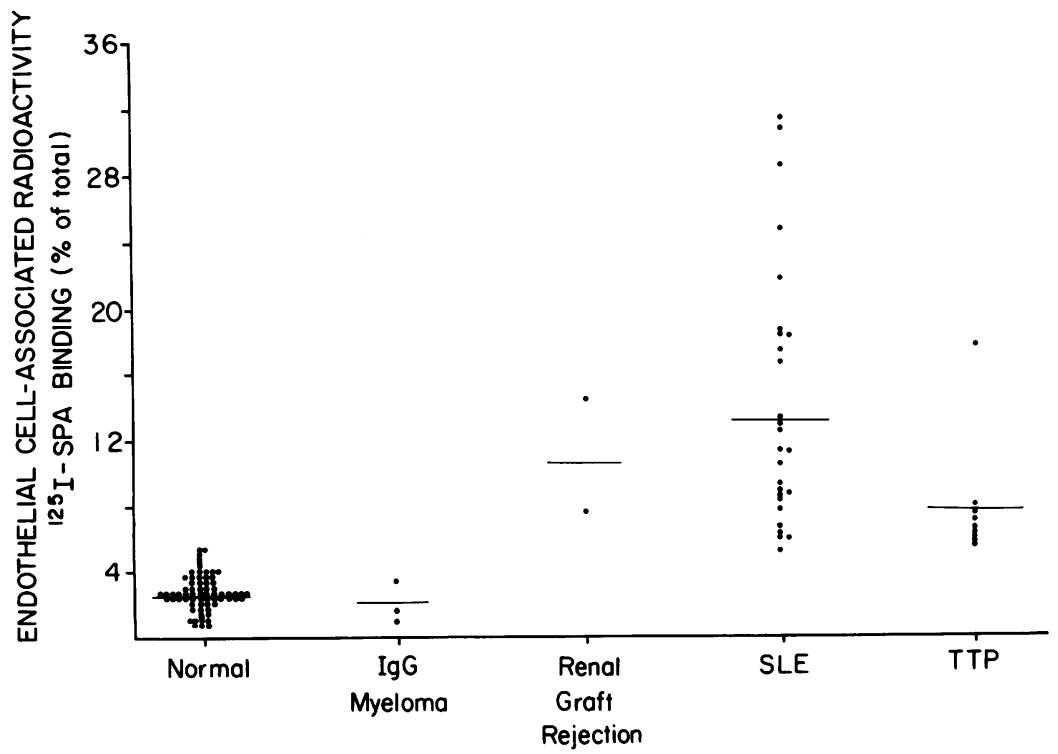

Figure 1. Binding of IgG to cultured endothelial cells determined by RIA. Endothelial monolayers were sequentially incubated with a source of human IgG, goat IgG anti-human IgG, and *SPA. The endothelial cell-associated radioactivity was determined. The solid line represents the mean binding for each study group. Each dot is the mean result of an individual sera performed in triplicate. 
were incubated with a source of IgG and then with goat antihuman IgG and finally with *SPA. In $>100$ individual experiments, little *SPA bound to cultured endothelial cells in the absence of a source of IgG $(0.6 \pm 0.2 \%$, mean $\pm S D)$. Sera from 86 healthy subjects caused $2.5 \pm 0.5 \%$ of the available *SPA to bind to the endothelial monolayer (Fig. 1). Similar results were obtained with sera from three patients with IgG myeloma. In contrast, sera from 27 patients with active SLE deposited $13.8 \pm 7.6 \%$ of the available ${ }^{*}$ SPA $(P<0.001)$. Sera from 24 of these 27 patients caused *SPA binding to the endothelium that was $>2$ SD from the mean value obtained using normal sera. However, sera from four SLE patients in a steroid-induced remission caused normal levels of *SPA binding (data not shown). There was no relationship between the serum IgG concentration or the level of Clq precipitins in the sera of these patients and the amount of IgG deposited on endothelial cells $(P>0.10)$ (data not shown).
We also studied sera from two patients who had rejected renal allografts, a condition in which endothelial antibodies have been previously demonstrated to occur (6-10). Both sera also had high titers of anti-HLA antibodies. These sera deposited increased amounts of IgG on endothelial cells, comparable to the amounts deposited by SLE sera (Fig. 1). Sera from eight of nine untransfused patients with newly diagnosed TTP caused only a modest increase in *SPA binding $(P=0.1)$.

Because binding of IgG to endothelial cells could be a property of cells in culture, studies were carried out with freshly isolated endothelial cells in suspension, using the Ortho Spectrum III fluorescence analyzer. Incubation of endothelial cell suspensions with normal IgG led to the deposition of small amounts of IgG, as had been observed with monolayers. Increased deposition of IgG was observed when suspension cells were incubated with SLE-IgG (Figs. 2 and 3). The binding of SLE-IgG to endothelial cells was confirmed by fluorescence microscopy. a

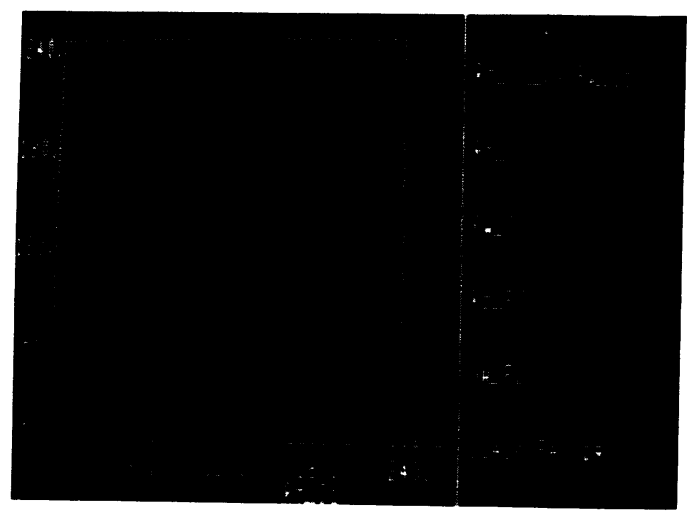

C

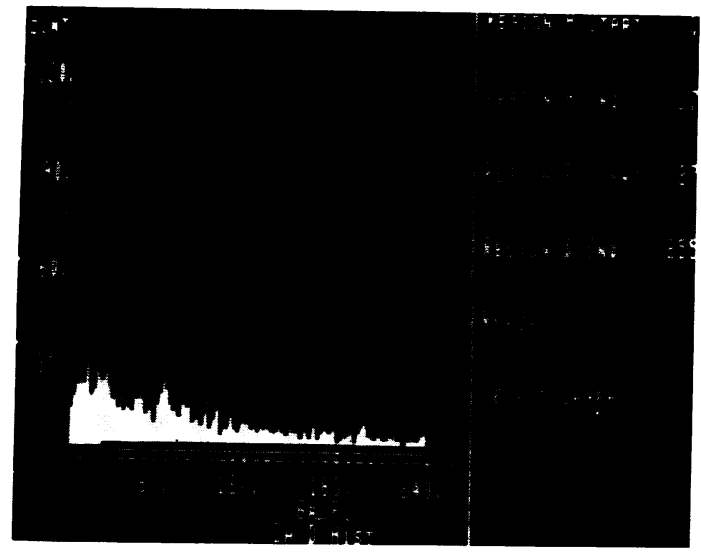

Figure 2. Binding of IgG to a suspension of endothelial cells assessed using the Spectrum III fluorescence analyzer. (a) Two-dimensional histogram of endothelial cells defining the cell region studied. Forward light scatter is shown on the ordinate, right angle scatter on the abscissa. $(b-d)$ Endothelial cells were incubated with $(b)$ monomeric

b

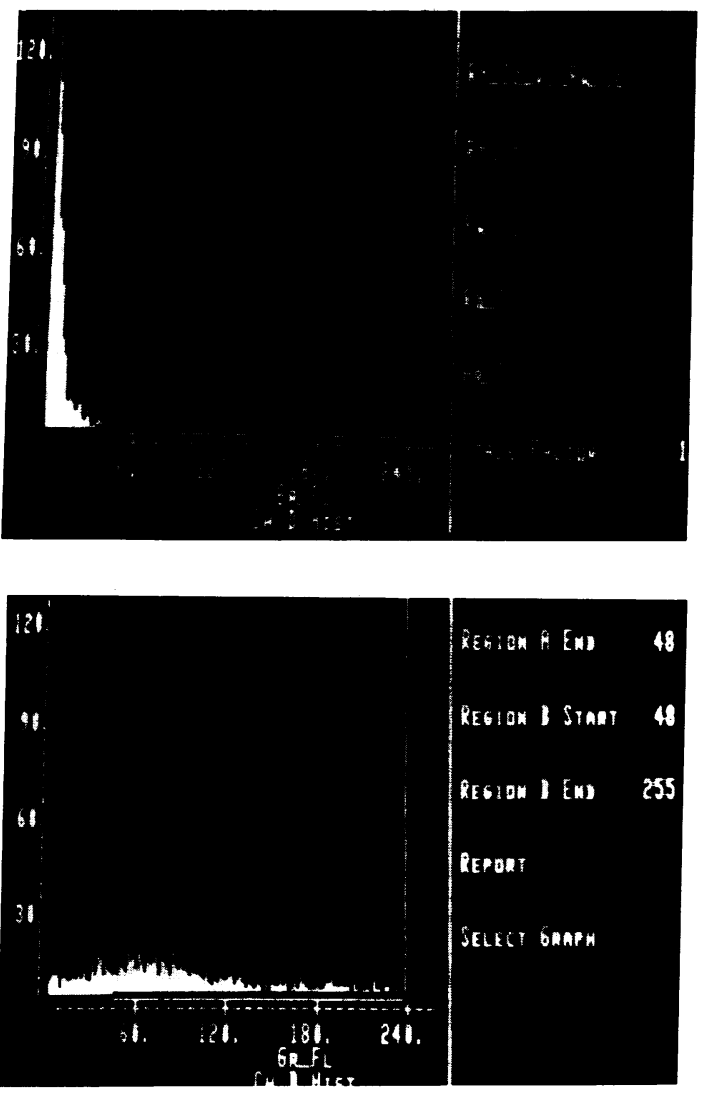

normal IgG, (c) HA-IgG, or (d) IgG from a patient with SLE. Sensitized cells were then incubated with goat anti-human FITC-conjugated Ig. In $b-d$, the number of analyzed cells is displayed along the ordinate. The amount of endothelial fluorescence is shown on the abscissa. 


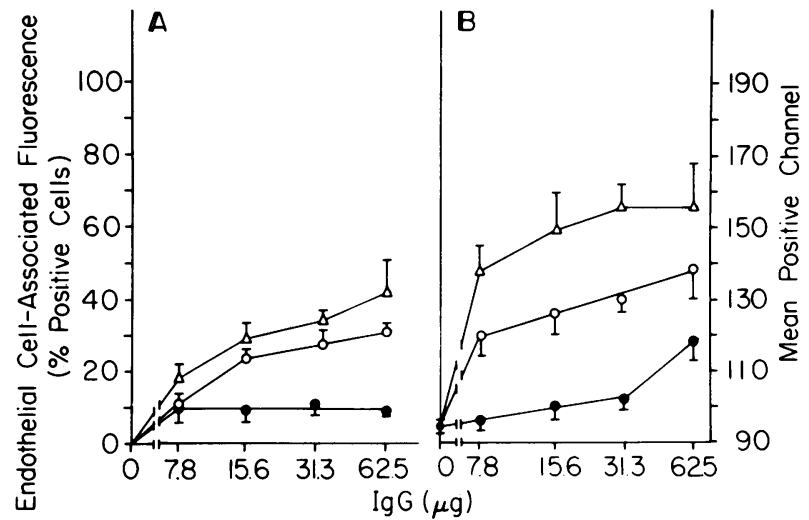

Figure 3. Binding of human IgG to endothelial cells using FITC-conjugated anti-IgG, analyzed on the Spectrum III. $(A)$ The percentage of cells with detectable fluorescence is shown. $(B)$ The mean positive channel of fluorescence is shown as a measure of the extent of binding of anti-Ig. Normal monomeric IgG (๑), SLE IgG ( $\Delta)$, HA-IgG (0). The mean \pm SEM of four to seven experiments at each point is shown.

\section{Mechanism of IgG binding}

SLE sera were further studied to determine whether the IgG associated with endothelial cells was monomeric (7S) antibody or higher molecular weight fractions, such as immune complexes. The monomeric (7S) IgG fractions from two SLE and two normal sera were separated from complexed IgG by Sephadex G200 chromatography. These $7 \mathrm{~S}$ fractions deposited $>80 \%$ as much IgG as was deposited on endothelial cells by the whole serum from which these 7S fractions were obtained (Fig. 4). Similar results were observed when these sera were fractionated following sucrose density ultracentrifugation (data not shown). The $\mathrm{F}\left(\mathrm{ab}^{\prime}\right)_{2}$ fragments of SLE-IgG or normal IgG also deposited $\sim 80 \%$ as much IgG on endothelial cells as the native IgG molecule (data not shown). In addition, at each concentration used, the binding of $F\left(a b^{\prime}\right)_{2}$ molecules to endothelial cells was greater when they were prepared from SLE-IgG than when they were prepared from normal IgG (Fig. 5). Therefore, binding of 7S SLE-IgG is not mediated primarily via an Fc receptor. Rather, IgG molecules in SLE sera bind to endothelial cell antigens predominantly in the form of monomeric endothelial antibodies. However, a small amount of IgG found in the higher molecular weight fractions $(>7 S)$ of SLE sera (present in the void volume of the Sephadex G-200 column) also binds to the endothelium (Fig. 4). This may represent immune complexes.

To further study the interaction of immune complexes with endothelial cells, we examined the binding of HA-IgG to endothelial cell monolayers (Fig. 6). IgG was detected on endothelial cells following the addition of 6-10 $\mu$ g of HA-IgG. This process was saturable; $\sim 90 \%$ of the maximum binding occurred following the addition of 200-250 $\mu \mathrm{g}$ protein. Monomeric normal IgG also bound to cultured endothelial cells, but $>10$-fold more protein was required for detection (Fig. 6). A similar binding pattern was observed when ${ }^{125} \mathrm{I}$-labeled heat-aggregated Fc fragments of IgG were used (data not shown). Over $90 \%$ of the binding of ${ }^{125} \mathrm{I}$-labeled $\mathrm{Fc}$ fragments was inhibited when the endothelial monolayer was preincubated with a 20 -fold excess of unlabeled HA-IgG; $<20 \%$ inhibition was observed using the same concentration of monomeric normal IgG. Preincubation with albumin did not inhibit the binding of ${ }^{125} \mathrm{I}-\mathrm{Fc}$ fragments to the endothelium. The binding of HA-IgG was also evident when freshly obtained endothelial cells were studied in suspension using the fluorescence analyzer (Figs. 2 and 3) and it was confirmed by direct fluorescence microscopy. Moreover, fluorescent microspheres coated with HA-IgG bound to the surface of the unfixed endothelial monolayer. In contrast, microspheres coated with equal concentrations of human albumin did not bind to endothelial cells (Fig. 7). Thus, immune complexes which contain IgG readily bind to the surface of endothelial cells in vitro.

Immune complexes can activate complement in fresh serum, and complement components can become incorporated into the protein matrix. Increased deposition of immune complexes may then occur on cells that have receptors for activated complement components. When HA-IgG was preincubated with

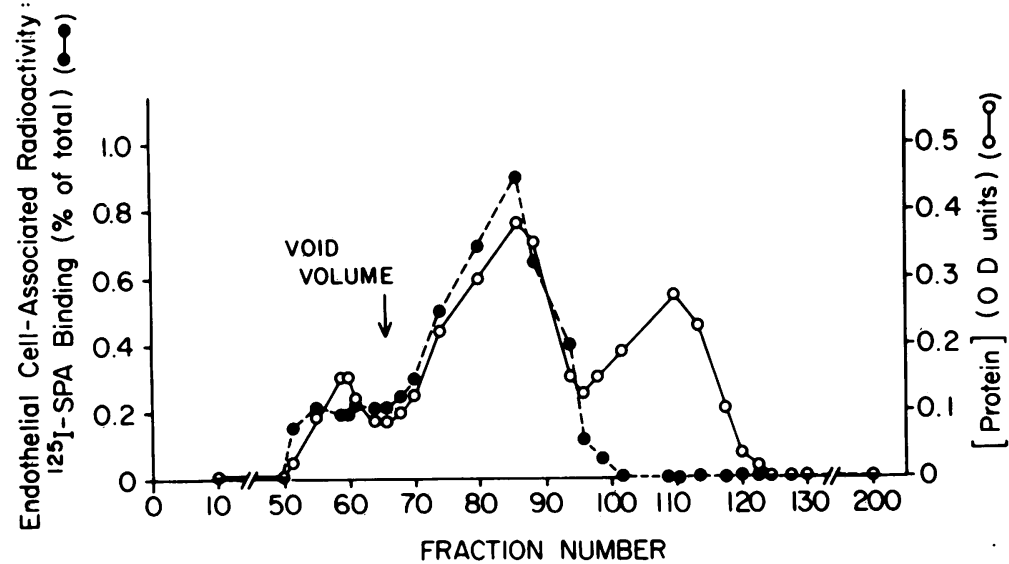

Figure 4. Serum from a patient with SLE was applied to a Sephadex G-200 column. The amount of protein in each $10-\mathrm{ml}$ fraction was determined by its light adsorbance at $280 \mathrm{~nm}$. A concentration of $\mathrm{IgG} \geq 0.01 \mathrm{mg} / \mathrm{ml}$ was restricted to fractions $66-105$ by radial immmunodiffusion (data not shown). The IgG antiendothelial cell activity of individual fractions was determined using antiIgG and *SPA. 


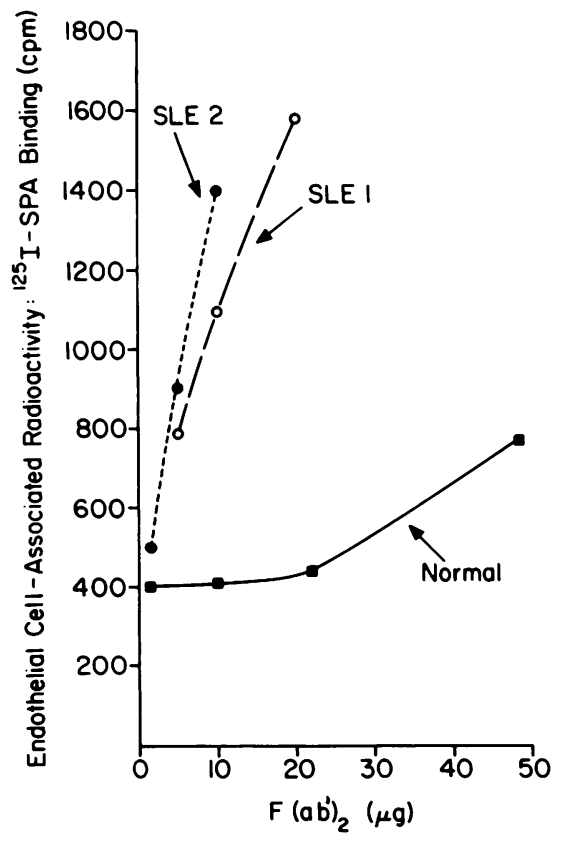

Figure 5. Endothelial cells were incubated with $\mathrm{F}\left(\mathrm{ab}^{\prime}\right)_{2}$ fragments of IgG from two normal individuals, shown as a mean, ( $-\square)$ and from two patients with $\operatorname{SLE}(\bullet---\bullet)(0--0)$ using anti-F $\left(\mathrm{ab}^{\prime}\right)_{2}$ and *SPA. The mean of two experiments is shown.

fresh normal human serum (a source of complement), increased quantities of IgG were bound to endothelial cells (Fig. 8). This augmentation occurred at concentrations of HA-IgG from 10 to $200 \mu \mathrm{g}$ (data not shown). The incubation of HA-IgG with

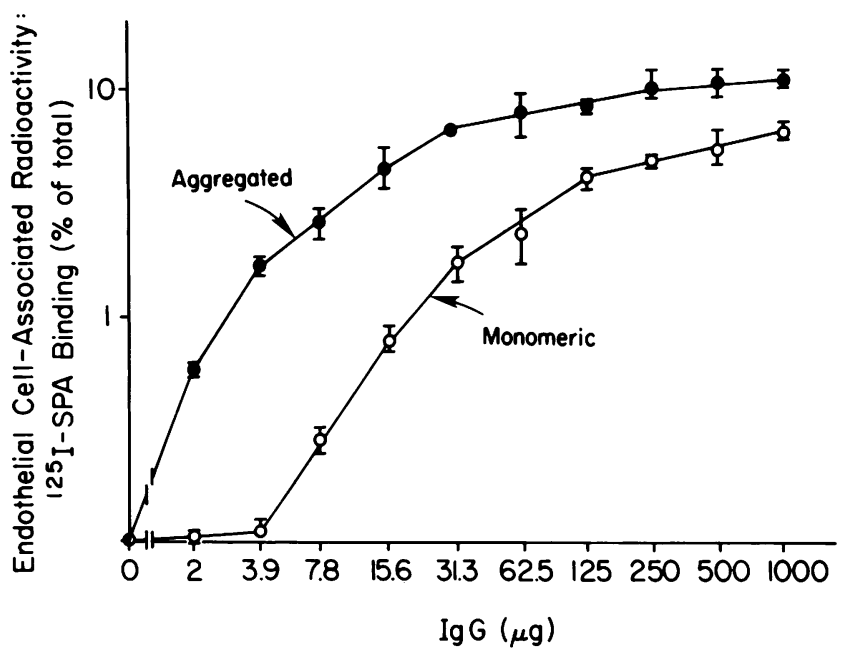

Figure 6. The binding of monomeric IgG (O) to endothelial cells is compared with that of HA-IgG (๑) using anti-human IgG and *SPA. Each experimental point was performed in triplicates. The mean \pm SEM of four experiments at each concentration is shown. Comparable results using HA-IgG were obtained in an additional 23 experiments. serum caused increased quantities of $\mathrm{C} 3$ to bind to the endothelial cell surface, as well (Fig. 8). In contrast, incubation of endothelial cells with normal serum alone caused the deposition of only small amounts of C3 (Fig. 8). The enhanced binding of both $\mathrm{IgG}$ and $\mathrm{C} 3$ to the endothelial cells observed when HA-IgG was preincubated with fresh serum was prevented by preheating the serum to $56^{\circ} \mathrm{C}$ or by the addition of EDTA (data not shown). Thus, endothelial cells are capable of binding complexed IgG and the binding is enhanced by the presence of serum, probably through complement activation.

\section{Specificity of IgG binding for endothelial cells}

Three SLE sera were tested with endothelial cells derived from 25 individual donors. There was approximately a twofold difference in the amount of IgG deposited on endothelial cells derived from different individual donors. However, SLE sera caused increased deposition of IgG onto the endothelial cells of every donor. In addition, three women with SLE delivered children during the course of this study. In each case, maternal SLE serum was equally reactive with the endothelial cells derived from their own neonate as from a random neonatal donor. Thus, the antigenic determinant recognized by SLE-IgG is present on endothelial cells derived from many donors.

The sera of patients with SLE have IgG antibodies that react with a variety of cells. Therefore, we carried out adsorption experiments to determine whether the antigen on endothelial cells recognized by SLE sera was also present on other normal hematopoietic cells (Fig. 9). The capacity of SLE sera to deposit IgG on endothelial cells was not removed by preincubation with erythrocytes, platelets, or T cells. In contrast, both $B$ cells and monocytes removed appreciable antiendothelial cell activity from the two SLE sera tested (Fig. 9). Similar results were obtained when the adsorption studies were repeated using $\mathrm{F}\left(\mathrm{ab}^{\prime}\right)_{2}$ molecules to exclude the possibility that $\operatorname{IgG}$ was adsorbed by the Fc receptors on B cells or monocytes.

Since D/DR antigens are present on $B$ cells and monocytes, we looked for the presence of DR on endothelial cells using both heterosera and monoclonal antibodies (Table I). Endothelial cells showed strong reactivity with W6/32, the monoclonal antiHLA framework antibody. Endothelial cells also bound detectable amounts of OKM1. In contrast, little or no specific binding of anti-D/DR antibodies could be demonstrated either on primary endothelial cell cultures or on freshly obtained endothelial cells in suspension using either anti-DR monoclonal antibodies or an anti-DR heteroserum. Moreover, the endothelial cells studied did not bind OKT11 or OKT3, excluding the presence of a significant number of $T$ lymphocytes in the endothelial population. Thus, the anti-endothelial cell antibodies in SLE sera could be serologically distinguished from antibodies directed at other cells.

\section{Consequences of the binding of IgG to endothelial cells}

Activation of complement. Following incubation with normal human serum, endothelial cells bound detectable amounts of C3 to the cell surface (Table II). Binding of C3 did not occur 

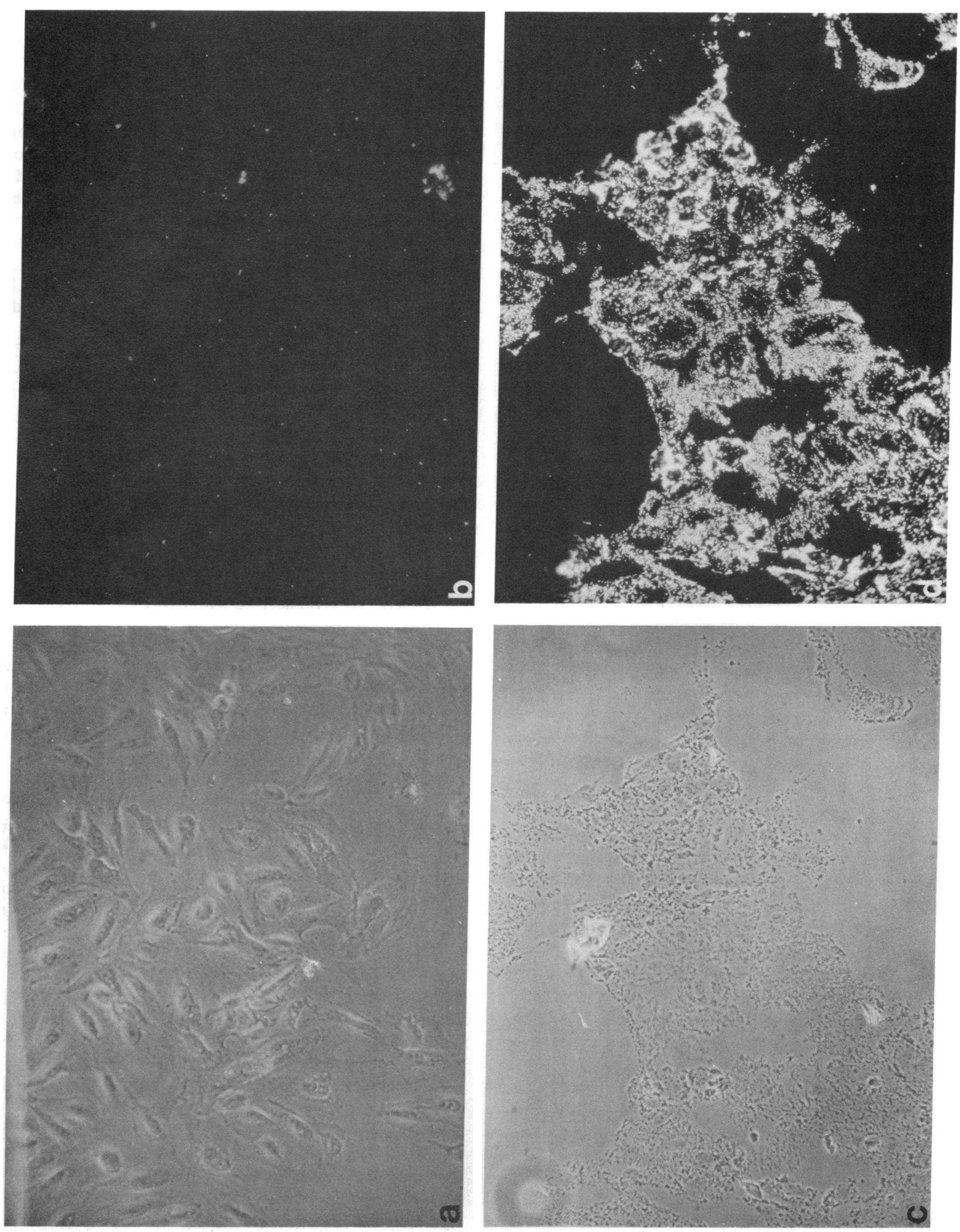


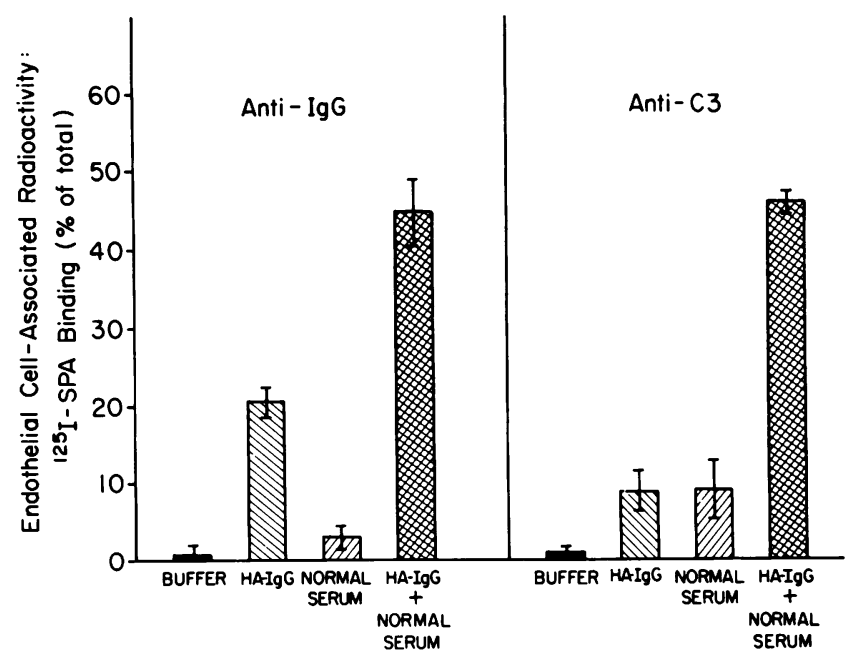

Figure 8. The effect of serum on the binding of HA-IgG to endothelial cells. HA-IgG $(200 \mu \mathrm{g})$ was incubated with a serum source of complement and then with endothelial cells. Sensitized cells were sequentially incubated with anti-IgG (left) or anti-C3 (right) and *SPA. The mean \pm SEM of three experiments is shown.

if the serum source of complement had been heat-inactivated or treated with EDTA. Incubation of the endothelial cells with normal, monomeric IgG did not increase $\mathrm{C} 3$ binding. In contrast, if the endothelial cells were first sensitized with HA-IgG, the addition of serum markedly increased the amount of endothelial cell-associated $\mathrm{C} 3$ that could be detected. Similarly, the IgG fraction from two SLE sera also enhanced C3 binding to endothelial cells following the addition of normal serum. This increase in $\mathrm{C} 3$ binding was prevented by inactivation of complement (Table II).

Secretion of $\mathrm{PGI}_{2}$. Endothelial cells secrete a small, but detectable amount of $\mathrm{PGI}_{2}$, and there is little binding of platelets to undisturbed endothelium. Binding of heat-aggregated IgG to endothelial cells caused a dose-dependent release of 6-keto-PGF $F_{1 a}$ (Fig. 10). At high concentrations of HA-IgG, the amount of 6keto-PGF I $_{\alpha}$ released was comparable to that released using thrombin as a stimulus. The IgG fraction of sera from two SLE patients also caused increased $\mathrm{PGI}_{2}$ release when compared with equivalent concentrations of normal monomeric IgG. Endothelial cells secreted $\mathrm{PGI}_{2}$ following a 10 -min exposure to thrombin. In contrast, HA-IgG caused a progressive increase in $\mathrm{PGI}_{2}$ release over $2 \mathrm{~h}$ (data not shown).

\section{Endothelial morphology and adherence of platelets}

Endothelial cells grown as monolayers retained their cobblestone appearance and remained contiguous following the addition of either normal IgG or normal serum (Fig. $11 A$ ). Endothelial

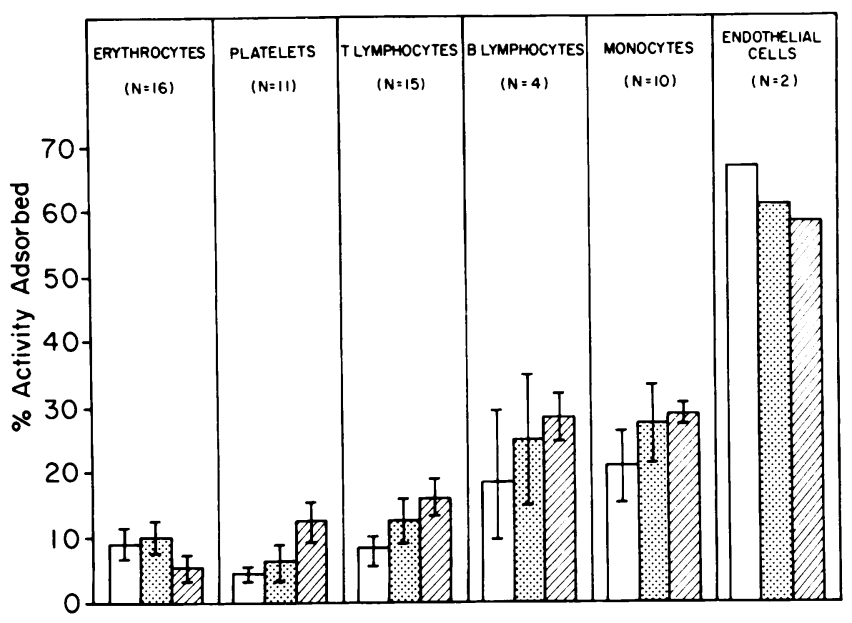

Figure 9. Binding of SLE-IgG to endothelial cells following incubation with other hematopoietic cells. IgG from two normal individuals (口) or from two patients with SLE $(\square, \mathbb{Q})$ were incubated with an equal volume of packed cells and the residual binding of IgG to endothelial cells was determined. Unadsorbed IgG served as a control for $100 \%$ activity. The mean \pm SEM of the percent endothelial cell-associated *SPA removed by adsorption was calculated. $\mathrm{N}$ represents the number of donors for each type of cell.

cells also remained adherent following exposure to SLE-IgG or HA-IgG. However, the cells separated from each other, with filamentous membrane fragments remaining adherent to the monolayer (Fig. $11 \mathrm{~B}$ ). Eventually, the cells assumed a rounded appearance (data not shown).

We observed little binding of platelets to cultured endothelial monolayers (Fig. 12). Platelet adherence was not increased by addition of normal monomeric IgG, normal sera or myeloma sera to the endothelium. In contrast, sensitization of the endothelium with HA-IgG caused a dose-dependent increase in platelet adherence, comparable in extent to that caused by thrombin (Fig. 12). Similarly, sera from 13 of 20 patients with active SLE increased platelet binding above the levels observed with normal serum (mean $+2 \mathrm{SD}$ ). The IgG fraction from two SLE patients studied also enhanced platelet binding (data not shown). Scanning electron microscopy confirmed the close physical association between the adherent platelets and the endothelial cells following sensitization of the latter with IgG (Fig. 11).

\section{Discussion}

Vascular endothelial cells form a barrier that may protect the vessel wall from the damaging effect of a variety of circulating plasma components. For example, during a normal immune
Figure 7. Binding of fluorescent microspheres coated with HA-IgG or human albumin to unfixed endothelial monolayers. (a) The endothelial monolayer is visible under phase contrast following incubation with albumin-coated microspheres. (b) Few albumin-coated beads are visible by fluorescence microscopy. (c) The details of the endothelial cell morphology are obscured by the overlying IgG-coated beads. $(d)$ Endothelial monolayer incubated with IgG-coated beads viewed by immunofluorescence showing intense cell-associated fluorescence. 
Table I. Binding of Monoclonal Antibodies to Endothelial Cells

\begin{tabular}{lcc}
\hline Antibody & Percent positive cells & Mean positive channel \\
\hline Buffer & $2.3 \pm 0.8$ & $94.7 \pm 10.2$ \\
P3 & $1.3 \pm 1.1$ & $90.4 \pm 6.6$ \\
W6/32 & $80.4 \pm 5.1$ & $153.8 \pm 7.2$ \\
Anti-Ia & & \\
CX 2.1 & $8.0 \pm 2.5$ & $113.2 \pm 11.6$ \\
OK-Ia & $5.6 \pm 0.9$ & $106.4 \pm 2.2$ \\
D-1-6 & 1.7 & 101.3 \\
691 & 2.0 & 97.7 \\
SK379 & 1.2 & 95.0 \\
Anti-mouse Ia & 2.0 & 98.2 \\
Lymphocyte & & \\
OKT3 & 0.8 & 90.1 \\
OKT9 & 0.2 & 94.1 \\
OKT11 & 1.1 & 91.7 \\
Miscellaneous & & \\
OKM1 & $15.8 \pm 6.2$ & $147.0 \pm 7.1$ \\
J5 & 0.4 & 90.3 \\
B1 & 0.9 & 110.4 \\
63XD3 & 1.2 & 97.6 \\
A 2 A & 1.6 & 94.1 \\
\hline
\end{tabular}

Binding of monoclonal antibodies to human endothelial cells. Endothelial cells in suspension were incubated with each monoclonal antibody (see Methods for antigen specificity of each antibody) and FITC sheep anti-mouse Ig and were analyzed on the Spectrum III fluorescence analyzer. The percentage of cells showing positive fluorescence and the mean positive channel of fluorescence, an indication of total antiglobulin binding, was determined. The mean \pm SEM of five experiments or the mean of two experiments is shown.

response to antigen, the endothelium is in contact with circulating antibody, immune complexes and activated complement components. Despite their presence in the circulation, immunoglobulin and complement are not generally found in vessel walls in vivo. Therefore normal endothelium appears to have a limited capacity to interact with either immune complexes or complement. However, in SLE and other forms of vasculitis, high titers of autoantibodies and immune complexes persist in the circulation, and immunoglobulin and complement are found in vessel walls. In the present study we sought to determine whether the vascular lesions that occur in SLE could result from direct injury to normal endothelium by antibody, immune complexes, or complement. These studies were performed using only endothelial cells derived from human umbilical veins. Therefore, these in vitro results may not entirely mirror the injury to blood vessels that occurs in vivo in patients with SLE.

Our studies demonstrate that sera from patients with active SLE deposit significant amounts of IgG onto endothelial cells. In this study we did not attempt to correlate this serum activity with clinical involvement of specific organs. However, this activity was no longer detectable when patients attained a clinical remission. SLE sera and its IgG fraction also fixed appreciable amounts of $\mathrm{C} 3$ to the endothelial cell surface. Furthermore, following interaction with SLE-IgG, the endothelial monolayer was disrupted. Individual cells lost contact with neighboring cells and assumed a rounded appearance. SLE-IgG caused secretion of $\mathrm{PGI}_{2}$ from the endothelium and platelets now adhered diffusely to the injured monolayer. The ability of SLE sera to deposit IgG on endothelial cells was found predominantly in the 7S fraction, and $F\left(a b^{\prime}\right)_{2}$ fragments of SLE-IgG retained antiendothelial activity. This suggests that the activity in SLE sera is primarily due to IgG anti-endothelial cell antibody. However, as noted below, a small amount of activity was also found in the higher molecular weight fractions, compatible with a lesser role for circulating immune complexes in causing endothelial injury.

In contrast, endothelial cells bound only small amounts of normal IgG and C3. Such binding may represent low levels of IgG complexes in normal serum but more likely represents naturally occurring antibodies against blood group or tissuespecific antigens, previously identified on endothelial cells (610). However, neither monomeric normal IgG nor normal serum appeared to damage the endothelial cells in vitro. The endothelial monolayers remained intact following exposure to normal serum. Adherence of normal platelets to endothelial cells was not observed. Furthermore, neither normal IgG nor normal serum caused the endothelial cells to secrete $\mathrm{PGI}_{2}$.

Table II. Binding of C3 to Endothelial Cells

\begin{tabular}{|c|c|c|c|c|}
\hline \multirow[b]{2}{*}{ Source of $\operatorname{Ig} G$} & \multicolumn{4}{|c|}{ Source of complement } \\
\hline & Buffer & $\begin{array}{l}\text { Normal } \\
\text { serum }\end{array}$ & $\begin{array}{l}\text { Heat- } \\
\text { inactivated } \\
\text { serum }\end{array}$ & $\begin{array}{l}\text { EDTA } \\
\text { serum }\end{array}$ \\
\hline None & $0.8 \pm 0.1$ & $7.2 \pm 1.2^{*}$ & $4.8 \pm 0.2$ & $3.2 \pm 0.1$ \\
\hline \multicolumn{5}{|c|}{ Monomeric IgG } \\
\hline $62.5 \mu \mathrm{g}$ & $0.4 \pm 0.1$ & $4.0 \pm 0.2$ & $4.2 \pm 0.4$ & $3.2 \pm 0.2$ \\
\hline $125 \mu \mathrm{g}$ & $0.4 \pm 0.3$ & $6.8 \pm 0.9$ & $5.2 \pm 0.2$ & $4.1 \pm 0.1$ \\
\hline \multicolumn{5}{|l|}{ SLE-IgG } \\
\hline $62.5 \mu \mathrm{g}$ & $10.2 \pm 1.6$ & $22.6 \pm 4.7$ & $11.2 \pm 1.8$ & $12.8 \pm 0.6$ \\
\hline $125 \mu \mathrm{g}$ & $16.4 \pm 0.3$ & $29.6 \pm 2.8$ & $13.6 \pm 0.8$ & $14.6 \pm 0.3$ \\
\hline \multicolumn{5}{|l|}{ HA-IgG } \\
\hline $62.5 \mu \mathrm{g}$ & $10.1 \pm 1.0$ & $27.6 \pm 6.0$ & $11.2 \pm 3.2$ & $11.8 \pm 1.6$ \\
\hline $125 \mu \mathrm{g}$ & $14.6 \pm 2.8$ & $30.8 \pm 5.9$ & $14.0 \pm 3.2$ & $16.0 \pm 3.9$ \\
\hline
\end{tabular}

The ability of endothelial-bound IgG to fix complement was determined. Endothelial cells were sequentially incubated with a source of $\mathrm{IgG}$, normal human serum (diluted 1:20) as a source of complement, IgG anti-C3, and *SPA. The mean \pm SEM of three to five experiments at each point is shown.

*In the absence of anti-C3, endothelial cells bound $4.2 \pm 0.4 \%$ of the available *SPA. 


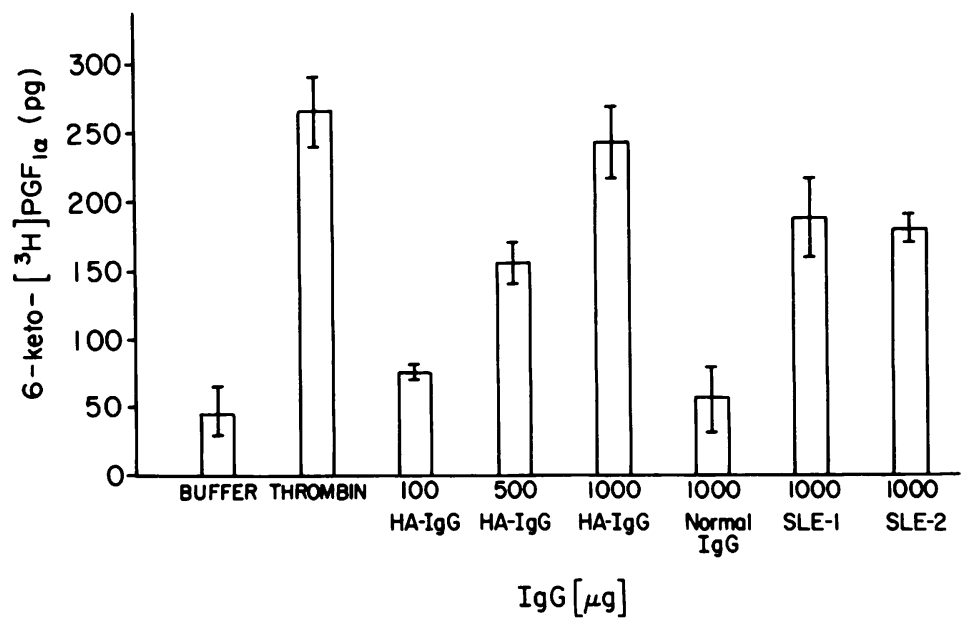

Figure 10. The effect of IgG on secretion of $\mathrm{PGI}_{2}$ by endothelial cells. Endothelial monolayers were incubated with normal monomeric IgG $(1,000 \mu \mathrm{g})$, two sources of SLE-IgG $(1,000 \mu \mathrm{g})$, or varying concentrations of HA-IgG $(100-1,000$ $\mu \mathrm{g})$ for $120 \mathrm{~min}$ at $37^{\circ} \mathrm{C}$, or thrombin $(1 \mathrm{U} / \mathrm{ml})$ for $10 \mathrm{~min}$ at $37^{\circ} \mathrm{C}$. The amount of $6-\mathrm{keto}^{3}\left[{ }^{3} \mathrm{H}\right] \mathrm{PGF}_{1 \alpha}$ in the media was determined. The mean \pm SEM of four experiments is shown.
The antigen recognized by SLE-IgG was present on the venous umbilical cells of all donors, including endothelial monolayers derived from three neonates born to mothers with SLE. Normal peripheral blood B cells and monocytes, but not erythrocytes, platelets, or T cells, adsorbed IgG antiendothelial activity from SLE sera. The failure to remove antiendothelial cell activity with the latter three cells demonstrates that endothelial antibodies in SLE are not identical to antibodies directed at erythrocyte blood groups, HLA antigens, or T cell antigens previously identified in SLE sera (38-40). The ability of B cells and monocytes to adsorb appreciable anti-endothelial cell antibody from SLE sera is compatible with the presence of $D / D R$ antigens on all three cell types. Endothelial cells have been demonstrated to express functionally active D/DR antigens on their cell surface (3) and patients with SLE have been shown to have anti-DR antibodies in their sera (39). However, we were unable to directly demonstrate DR antigens on most cultured endothelial cells by fluorescence analysis or by enzyme-linked immunosorbent assay (unpublished observations). To date, studies that have directly identified DR antigens on cultured endothelial cells have primarily used heterosera or human allosera. D/DR antigens have been identified by immunofluorescence on capillary endothelial cells, but not on cells derived from umbilical vein(s) (7). Our inability to detect $\mathrm{D} / \mathrm{DR}$ determinants on most of these cells may also reflect the fact that the antibodies we used were primarily monoclonal antibodies, which generally recognize restricted regions of framework determinants of DR present on $B$ cells or malignant cells. These specific DR determinants may not be expressed on endothelial cells. Alternatively, the expression of D/DR antigens may be restricted to a small subpopulation of endothelial cells (41). In addition, enzymatic treatment of endothelial cells with collagenase during their isolation and aging of cells during culture may also have affected the expression of portions of the D/DR molecule (42). Recent studies suggest that the expression of $D / D R$ by endothelial cells may require or may be augmented by specific stimulation not present in our culture system $(43,44)$. Alternatively, the anti-endothelial an- tibodies in SLE sera that we observed may be directed, at least in part, towards other non-DR antigens shared with B cells and monocytes, such as those that may be involved in renal allograft rejection (8-10). The low level of $\mathrm{D} / \mathrm{DR}$ - or $63 \mathrm{XD3}$-positive cells suggests that large numbers of macrophages are not present in our endothelial cell preparations. However, the binding of OKM1 to a portion of these cells may indicate that a structure antigenically similar to the monocyte $\mathrm{C} 3 \mathrm{bi}$ receptor is also present on cultured endothelial cells (45).

The presence of IgG-containing immune complexes may also account for a portion of the IgG deposited on endothelial cells by SLE sera. The high molecular fractions of SLE serum, but not normal serum, deposited IgG on endothelial cells following separation on either a sucrose density gradient or by Sephadex G-200 chromatography. To directly determine whether immune complexes might become cell-associated, we studied the binding of HA-IgG to endothelial cells. HA-IgG bound to endothelial cells in a saturable manner and bound with greater avidity than monomeric IgG. Preincubation of HA-IgG with a serum source of active complement markedly augmented the binding of both HA-IgG and C3 to endothelial cells. The failure of heat-inactivated or EDTA-treated serum to augment binding of HA-IgG suggests that cultured endothelial cells may possess a receptor for one or more activated complement components $(17,46)$. Furthermore, at concentrations of HA-IgG found in SLE sera, endothelial-bound HA-IgG activated the complement system on the endothelial cells, disrupted the monolayer, initiated $\mathrm{PGI}_{2}$ secretion and caused the monolayer to be covered with adherent platelets. Therefore, our data indicate that SLE sera injure venous endothelial cells in vitro by depositing both antiendothelial antibodies and IgG-containing immune complexes on the surface of these cells. It should be noted that these studies using the SPA radioimmunoassay permitted the detection of immune complex deposition, whereas studies in our laboratory (12) and others $(11,13)$ using erythrocyte rosettes as the assay tool, were unable to detect the binding of complexed IgG by endothelial cells. 

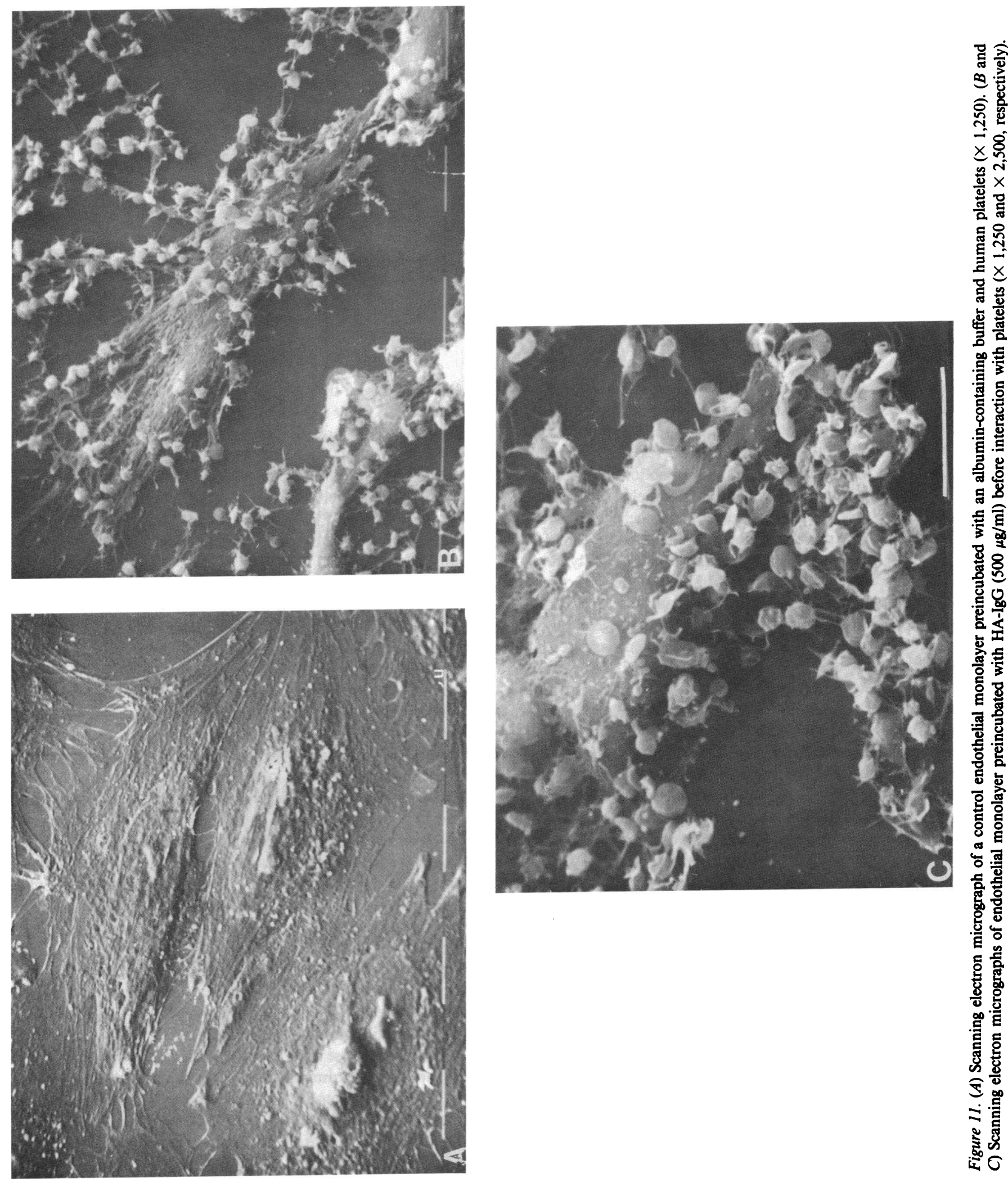


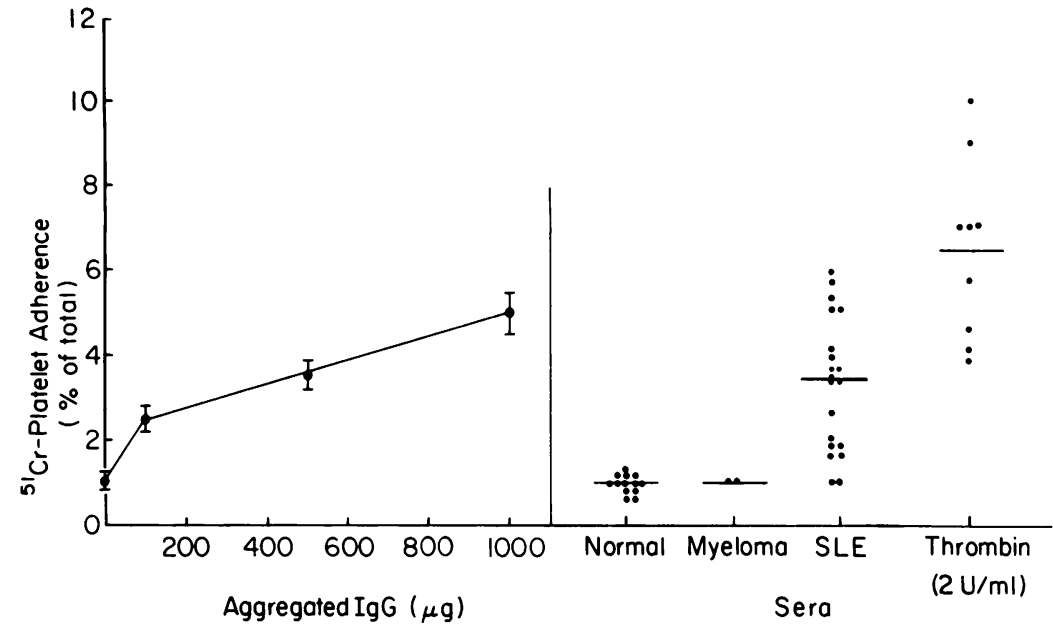

The presence of anti-endothelial antibodies may not be restricted to patients with SLE. We also observed that sera from two patients who had rejected renal allografts deposited increased amounts of IgG on endothelial cells. Antibodies to endothelial cells have recently been implicated in the development of experimental and clinical allograft rejection $(6-10,47)$. The ability to rapidly determine the presence of anti-renal endothelial cell antibodies in the sera of potential recipients by the techniques described, may help improve donor transplant selection. In addition, our findings are compatible with the recently reported finding of anti-endothelial antibodies or IgG-containing immune complexes in the sera of some patients with TTP (48); however, the titers of activity in most sera of patients with TTP were below those found in patients with active SLE. Finally, IgG and IgM autoantibodies to intermediate filaments and other cytoplasmic antigens within endothelial cells have been noted in a wide variety of disorders and may be present in some normal sera as well (49-51). However, these antibodies, which are evident following disruption of the outer cell membrane appear to bear no direct relationship to the surface antibodies in SLE that we describe.

Immune injury to endothelial cells by either antibody or by immune complexes caused the adherence of normal platelets. This may have been due to the exposure of additional binding sites for Factor VIII antigen or new determinants that promote platelet adherence. Alternatively, surface-bound IgG may have served as a bridge between the endothelium and the Fc receptors on human platelets. Regardless of which mechanism was operative, the secretion of $\mathrm{PGI}_{2}$ following immune injury in vitro was insufficient to completely prevent platelet adherence. Similar observations have been made following thrombin-mediated endothelial injury (37). Surface-bound IgG may also serve to localize leukocytes to vascular tissues, as occurs in both acute and chronic vasculitis in man (1).

In each disorder in which immune endothelial injury has been demonstrated, including SLE, differences between in vitro
Figure 12. Adherence of platelets to endothelial monolayers. Endothelial monolayers were preincubated with a source of human IgG or with thrombin and washed. The percent adherence of ${ }^{51} \mathrm{Cr}$ labeled washed platelets to the monolayer was determined. The mean \pm SEM of seven experiments is shown. binding assays and the genesis of vasculitis in vivo are apparent. It is clear that not all endothelial cell surfaces are involved at all times during active immune vasculitis. Conditions that influence the binding of antibody and IgG-complexes to the endothelium in vivo remain uncertain. We and others have shown that viral infection alters the endothelial surface and promotes the binding of immune complexes not containing anti-viral antibodies $(11,12)$. Other factors may also modulate the susceptibility to immune injury, including exposure of internal antigens. In addition, there may be differences in surface antigens and receptor density on endothelial cells at different vascular sites. The present study serves to provide evidence that endothelium, possibly modified by various influences in vivo, may be involved in the initiation of immune vascular injury at these separate sites.

\section{Acknowledgments}

We thank Rena Finko, Krystyna Knight, and Phillip Michaels for their expert technical assistance. We thank Mrs. Patricia Lafferty for preparation of the manuscript.

This work was supported, in part, by grants 1-RO1-HL28220 and 1-F32-HL06394 from the National Institutes of Health and grants from the Commonwealth of Pennsylvania and the Lupus Foundation.

\section{References}

1. Fauci, A. S., B. F. Haynes, and P. Katz. 1978. The spectrum of vasculitis. Clinical, pathologic, immunologic, and therapeutic considerations. Ann. Intern. Med. 89:660-676.

2. Cochrane, C. G. 1971. Mechanisms involved in the deposition of immune complexes in tissue. J. Exp. Med. 134(3, Pt. 2): 75s-89s.

3. Hirschberg, H., O. J. Bergh, and E. Thorsby. 1980. Antigenpresenting properties of human vascular endothelial cells. J. Exp. Med. 152(2, Pt. 2):249s-255s.

4. Stevens, S. K., I. L. Weissman, and E. C. Butcher. 1982. Differences in the migration of $\mathrm{B}$ and $\mathrm{T}$ lymphocytes: organ selective localization 
in vivo and the role of lymphocyte-endothelial cell recognition. J. Immunol. 128:844-851.

5. Lauterburg, W., B. Ryffel, H. Buerki, M. W. Hess, H. Cottier and R. D. Stoner. 1980. Increased lymphocyte load of postcapillary venules in regional lymph nodes following stimulation with antigenisologous antibody complexes as compared with antigen alone. Blood Cell. 6:41-51.

6. Paul, L. C., L. A. van Es, and W. M. Baldwin III. 1981. Antigens in human renal allografts. Clin. Immunol. Immunopathol. 19:206-223.

7. Scott, H., P. Brandtzaeg, H. Hirschberg, B. G. Solheim, and E. Thorsby. 1981. Vascular and renal distribution of HLA-DR-like antigens. Tissue Antigens. 18:195-202.

8. Moreas, J. R., and P. Stastny. 1977. A new antigen system expressed in human endothelial cells. J. Clin. Invest. 66:449-454.

9. Cerilli, J., and L. Brasile. 1980. Endothelial cell alloantigens. Transplant. Proc. 12(Suppl. 1):37-42.

10. Paul, L. C., and C. B. Carpenter. 1980. Antibodies against renal endothelial alloantigens. Transplant. Proc. 12(Suppl. 1):43-48.

11. Ryan, V. S., D. R. Schultz, and J. W. Ryan. 1981. Fc and C3b receptors on pulmonary endothelial cells: induction by injury. Science (Wash. DC). 214:557-558.

12. Cines, D. B., A. P. Lyss, M. Bina, R. Corkey, N. A. Kefalides, and H. M. Friedman. 1982. Fc and C3 receptors induced by herpes simplex virus on cultured human endothelial cells. J. Clin. Invest. 69:123128.

13. Ryan, V. S., D. R. Schultz, P. J. Del Vecchio, and J. W. Ryan. 1980. Endothelial cells of bovine pulmonary artery lack receptors for $\mathrm{C} 3 \mathrm{~b}$ and for the Fc portion of immunoglobulin G. Science (Wash. DC) 208:748-749.

14. Fillit, H. M., E. A. Jaffe, and J. B. Zabriskie. 1982. In vitro correlates of endothelial injury and repair. Lab. Invest. 46:1-9.

15. Hansson, G. K., T. Bjornheden, A. Bylock, and G. Bondjers. 1981. Fc-dependent binding of monocytes to areas with endothelial injury in the rabbit aorta. Exp. Mol. Pathol. 34:264-280.

16. Shingu, M., Y. Hashimoto, A. R. Johnson, and E. R. Hurd. 1981. The search for Fc receptors on human tissues and human endothelial cells in culture. Proc. Soc. Exp. Biol. Med. 167:147-155.

17. Andrews, B. S., M. Shadforth, P. Cunningham, and J. S. Davis IV. 1981. Demonstration of a Clq receptor on the surface of human endothelial cells. J. Immunol. 127:1075-1080.

18. Sordat, B., M. W. Hess, and H. Cottier. 1971. IgG immunoglobulin in the wall of post-capillary venules: possible relationship to lymphocyte recirculation. Immunology. 20:115-118.

19. Jaffe, E. A., R. L. Nachman, C. G. Becker, and C. R. Minick. 1973. Culture of human endothelial cells derived from umbilical veins. Identification by morphologic and immunologic criteria. J. Clin. Invest. 52:2745-2756.

20. Gimbrone, M. A., R. S. Cotran, and J. Folkman. 1974. Human vascular endothelial cells in culture. Growth and DNA synthesis. J. Cell Biol. 60:673-684.

21. Maciag, T., J. Cerundolo, S. Ilsley, P. R. Kelley, and R. Forand. 1979. An endothelial cell growth factor from bovine hypothalamus: identification and partial characterization. Proc. Natl. Acad. Sci. USA. 76:5674-5678.

22. Booyse, F. M., A. J. Quarfoot, J. Chediak, M. B. Stemerman, and T. Maciag. 1981. Characterization and properties of cultured human von Willebrand umbilical vein endothelial cells. Blood. 58:788-796.

23. Jaffe, E. H., L. W. Hoyer, and R. L. Nachman. 1973. Synthesis of antihemophiliac factor antigen by cultured human endothelial cells. J. Clin. Invest. 52:2757-2764.
24. DeHoratius, R. J., K. S. K. Tung, and T. Pincus. 1980. Reduced T lymphocyte subsets in systemic lupus erythematosus: effects of immune complexes and lymphocytotoxic antibodies. Clin. Immunol. Immunopathol. 17:245-256.

25. Cines, D. B., and A. D. Schreiber. 1979. Immune thrombocytopenia: use of a Coombs' antiglobulin test to detect IgG and $\mathrm{C} 3$ on platelets. N. Engl. J. Med. 300:106-110.

26. Nisonoff, A., F. C. Wissler, L. N. Lipman, and D. L. Woernley 1960. Separation of univalent fragments from the bivalent rabbit antibody molecule by reduction of disulfide bonds. Arch. Biochem. Biophys. 89:230-244.

27. Laemmli, U. K. 1970. Cleavage of structural proteins during the assembly of the head of bacteriophage T4. Nature (Lond.). 227:680685.

28. Mancini, G., A. O. Carbonara, and J. F. Heremans. 1965. Immunochemical quantification of antigens by single radial immunodiffusion. Immunochemistry. 2:235-254.

29. Starkebaum, G., T. H. Price, M. Y. Lee, and W. P. Arend. 1978 Autoimmune neutropenia in systemic lupus erythematosus. Arthritis Rheum. 21:504-512.

30. Kurlander, R. J. 1980. Reversible and irreversible loss of Fc receptor function of human monocytes as a consequence of interactions with immunoglobulin G. J. Clin. Invest. 66:773-781.

31. Pelligrino, M. A., S. Ferrone, M. P. Dierich, and R. A. Reisfeld. 1978. Enhancement of sheep red blood cell human lymphocyte rosetteformation by the sulfhydryl compound 2-aminoethylisothiournium bromide. Clin. Immunol. Immunopathol. 3:324-329.

32. McConahey, P. J., and F. J. Dixon. 1966. A method of trace iodination of proteins for immunologic studies. Int. Arch. Allergy Appl. Immunol. 29:185-189.

33. Bennett, J. S., J. A. Hoxie, S. F. Leitman, G. Vilaire, and D. B. Cines. 1983. Inhibition of fibrinogen binding to stimulated human platelets by a monoclonal antibody. Proc. Natl. Acad. Sci. USA. 80:24172421.

34. Ip, S. H., C. W. Ritterhaus, C. C. Struzziero, J. A. Hoxie, R. A. Hoffman, K. W. Healey, and J. Lifter. 1982. Evaluation of E-rosetting human lymphocytes with OKT11 and other monoclonal antibodies. Blood. 60:795-799.

35. Goldman, M. 1968. Labeling agents and procedures for conjugation. In Fluorescent Antibody Methods. Academic Press, Inc., New York. 97.

36. Fallon, J. R., and V. T. Nachmias. 1980. Localization of cytoplasmic and skeletal myosins in developing muscle cells by doublelabel immunofluorescence. J. Cell Biol. 87:209-218.

37. Czervionke, R. L., J. C. Hoak, and G. L. Fry. 1978. Effect of aspirin on thrombin-induced adherence of platelets to cultured cells from the blood vessel wall. J. Clin. Invest. 62:847-856.

38. Sakane, T., A. D. Steinberg, J. Patton-Reeves, and I. Green 1979. Studies of immune function of patients with systemic lupus erythematosus. Complement-dependent immunoglobulin $\mathbf{M}$ antithymusderived cell antibodies preferentially inactivate suppressor cells. J. Clin. Invest. 63:954-965.

39. Okudaira, K., R. P. Searles, J. L. Ceuppens, J. S. Goodwin, and R. C. Williams, Jr. 1982. Anti-Ia reactivity in sera from patients with systemic lupus erythematosus. J. Clin. Invest. 69:17-24.

40. Williams, R. C. 1982. Antibodies in systemic lupus-diversity finally simplified. J. Lab. Clin. Med. 100:161-164.

41. Nunez, G., E. J. Ball, and P. Stastny. 1983. Accessory cell function of human endothelial cells. I. A subpopulation of Ia positive cells is required for antigen presentation. J. Immunol. 131:666-673. 
42. Hirschberg, H., T. Moen, and E. Thorsby. 1979. Specific destruction of human endothelial cell monolayers by anti-DRw antisera. Transplantation (Baltimore). 28:116-120.

43. Pober, J. S., and M. A. Gimbrone, Jr. 1982. Expression of Ialike antigens by human vascular endothelial cells is inducible in vitro: demonstration by monoclonal antibody binding and immunoprecipitation. Proc. Natl. Acad. Sci. USA. 79:6641-6645.

44. Pober, J. S., M. A. Gimbrone, Jr., R. S. Cotran, C. S. Reiss, S. J. Burakoff, W. Fiers, and K. A. Ault. 1983. Ia expression by vascular endothelium is inducible by activated $\mathrm{T}$ cells and by human interferon. J. Exp. Med. 157:1339-1353.

45. Wright, S. D., P. E. Rao, W. C. VanVoorhis, L. S. Craigmyle, K. Iida, M. A. Talle, E. F. Westberg, G. Goldstein, and S. C. Silverstein. 1983. Identification of the C3bi receptor of human monocytes and macrophages by using monoclonal antibodies. Proc. Natl. Acad. Sci. USA. 80:5699-5703.

46. Linder, E. 1981. Binding of Clq and complement activation by vascular endothelium. J. Immunol. 126:648-658.
47. Dvorak, H. F., M. C. Mihm, Jr., A. M. Dvorak, B. A. Barnes, E. J. Manseau, and S. J. Gall. 1979. Rejection of first-set skin allografts in man. The microvasculature is the critical target of the immune response. J. Exp. Med. 150:322-337.

48. Burns, E. R., and D. Zucker-Franklin. 1982. Pathologic effects of plasma from patients with thrombotic thrombocytopenic purpura on platelets and cultured vascular endothelial cells. Blood. 60:10301037.

49. Lindquist, K. J., and C. K. Osterland. 1971. Human antibodies to vascular endothelium. Clin. Exp. Immunol. 9:753-760.

50. Linder, E., M. Hormia, V.-P. Lehto, and T. Tornroth. 1981. Identification of cytoskeletal intermediate filaments of vascular endothelial cells as targets for autoantibodies in patient sera. Clin. Immunol. Immunopathol. 21:217-227.

51. Shingu, M., and E. R. Hurd. 1981. Sera from patients with systemic lupus erythematosus reactive with human endothelial cells. $J$. Rheumatol. 8:581-586. 